\title{
Reservoir types and regional accumulation characteristics of pear rift
}

\author{
SUN Yu ${ }^{1, a}$, YUAN Hongqi $i^{2, b}$ \\ ${ }^{1}$ Northeast Petroleum University of Daqing City, Heilongjiang province in China \\ ${ }^{2}$ Northeast Petroleum University of Daqing City, Heilongjiang province in China \\ a1473262934@qq.com, b852384299@163.com
}

Keywords:Reservoir type, Songliao Basin, Pear rift, Structural features,Shahezi,Yingchengzu..

\begin{abstract}
Reservoir types and distribution of water is an important part of petroleum geology studies, selection and knowledge of the oil and gas exploration direction of hydrocarbon accumulation rules are important. The use of logging while drilling, a variety of three-dimensional seismic and geological data provided by the site.Fine reservoir anatomy purpose is known reservoir of available information on the difficult issues of reservoir development process focused on block-depth analysis, in order to achieve the same type of speculation from known reservoirs unknown obtain reservoir expansion side scrolling development direction.
\end{abstract}

Pear rift located southeast uplift area of Songliao basin, faulted area of nearly $2300 \mathrm{~km} 2$, the maximum depth of the base more meters, since the Early Cretaceous developed from broken Au stacked composite basin, the western boundary by the curved rupture (Mulberry NTU dustpan fracture) controlled rift. Today profile rift morphology can be divided into upper and lower two-tier structure, mulberry station fracture as the main control pear rift basin depression fracture control, control of the same sequence of rift formation and distribution off the east and west over the dustpan rift style. Occurrence gentle, thickness and distribution of more stable depression sequence overlying basal rift sequences and sequence.

Pear rift rich oil and gas resources, it has already discovered oil and gas fields SIWUJIAZI, after five household gas field, GUJIAZI field, Taiping Oilfield, Qin jiatun oil and gas fields, gas fields and leather home Jinshan gas field 15 oil and gas fields, the cumulative reported 94,720,400 tons of proven oil reserves, the cumulative reported proven natural gas reserves of 75.819 billion square geological exploration with remarkable results. Find out the reservoir type, distribution and main controlling factor is the basis for evaluation of zone and key objectives preferred. Therefore, this chapter will have been found in oil and gas fields (reservoirs) of oil and gas distribution, a comprehensive analysis of the law of accumulation, production information, etc. based on the results, divide reservoir type, carry typical anatomical reservoirs, clear accumulation main factor.

Reservoir types and distribution of water is an important part of petroleum geology studies, selection and knowledge of the oil and gas exploration direction of hydrocarbon accumulation rules are important. Songliao Basin rift pear accumulation conditions and water distribution complex, rich reservoir type. The use of logging while drilling, a variety of three-dimensional seismic and geological data provided on site for 196 wells fine anatomical reservoirs provide the basis for summary analysis of reservoir types and distribution of oil and water.

\section{Reservoir type}

To dissect reservoirs, the first evaluation of all oil and gas fields in the study area (Tibet) and statistical analysis of the basic characteristics, reservoir types seriously divided. Currently, the reservoir type of partitioning scheme many different angles have different solutions. Generally there are several options: First, trap type is mainly based on the type of division of oil and gas reservoirs, as typical examples of Zhang Wenzhao (1990) findings (Table 1-1); the second is based on the hydrocarbon phase, the reservoir into the reservoir, the reservoir gas cap, ring gas reservoir with oil and gas reservoirs and gas condensate reservoir; the third is by the reservoir forms the reservoir into a layered, massive and lenticular reservoirs and other types. 
Table 1-1 reservoir trap type table

\begin{tabular}{|c|c|c|c|}
\hline Structural trap reservoirs & $\begin{array}{l}\text { Lithologic trap } \\
\text { reservoirs }\end{array}$ & $\begin{array}{l}\text { Stratigraphic trap } \\
\text { reservoirs }\end{array}$ & Complex trap reservoirs \\
\hline $\begin{array}{l}\text { (1Anticline reservoirs } \\
\text { (1) Anticline or semi anticline } \\
\text { (2) Buried hill or bedrock uplift } \\
\text { (3) Syndepositional anticline } \\
\text { (4) Rollover anticline } \\
\text { (5) Anticlinal upliftlatent plasticity } \\
\text { (2) Fault trap reservoir } \\
\text { (1) Fault nose structure } \\
\text { (2) Thrust } \\
\text { (3) Saggered fault } \\
\text { (4) Block } \\
\text { (5) Bending fault } \\
\text { (3) Pierce trap reservoirs }\end{array}$ & $\begin{array}{l}\text { (1) Sandstone reservoirs } \\
\text { convex mirror body } \\
\text { (2)Convex mirror body } \\
\text { limestone reservoirs } \\
\text { (3)Channel sandstone } \\
\text { reservoirs } \\
\text { (4)Pour off the tip of } \\
\text { lithologic reservoirs } \\
\text { (5)Blocks of reef } \\
\text { reservoir }\end{array}$ & $\begin{array}{l}\text { (1)Stratigraphic } \\
\text { unconformity reservoir } \\
\text { (1) The unconformity } \\
\text { (2) Lower unconformity } \\
\text { (2) Super overlying } \\
\text { unconformity reservoirs } \\
\text { (3)erosion unconformity } \\
\text { reservoirs }\end{array}$ & $\begin{array}{l}\text { (1)Structural-lithological } \\
\text { reservoirs } \\
\text { (2)Structural-stratigraphic } \\
\text { reservoirs } \\
\text { (3)Structure-fluid reservoir }\end{array}$ \\
\hline
\end{tabular}

Because pear faulted reservoirs mainly Cretaceous rift within the next layer of the system, as well as part of the hill reservoir, reservoir types currently found mainly block, broken nose and anticline structure reservoir, such large-scale reservoir; secondly there lithologic reservoir and structural - lithologic composite reservoir to construct position + trap type as a basis for classification and analysis of oil and gas reservoirs, concrete results in Table 1-2.

Upon completion of classification should choose typical anatomical reservoirs. Because pear faulted reservoirs distributed along three major strike-slip tectonic zone distribution, each with varying degrees of structural discovery, especially the central uplift belt discovered a series of gas reservoirs, reservoirs and reservoir. Recently achieved a major breakthrough with the southeast slope, discovered a series of reservoirs, and the degree of evolution due to the strength of the various different tectonic belt, reservoir characteristics are not the same, so this one is a typical reservoir anatomical principles are considered each band to select a target anatomy, and second, taking into account the distribution of oil and gas, and strive gas reservoirs and reservoir are chosen target anatomy. However, according to the actual situation, this time selecting the southeast slope with hotspots Qin jiatun oil and gas fields were dissected, reservoirs other anatomical structures with its combination of exploration targets, and targets in the key area of evaluation were elaborated with the preferred section.

Table 1-2 pear rift main reservoir characteristics table

\begin{tabular}{|c|c|c|c|}
\hline \multirow{2}{*}{ Oil and gas fields (Tibet) } & Structural position & Reservoir construction & Non-structural reservoir \\
\hline & Second & Type & Type \\
\hline Houwujia gas fields & \multirow{6}{*}{ Central uplift belt } & block fault & lithology \\
\hline Bawu gas fields & & saddle & composite \\
\hline Shiwu oil and gas fields & & saddle & lithology \\
\hline Gujiazi gas fields & & fault & \\
\hline Siwujiazi gas fields & & saddle & \\
\hline Taipingzhuang oil fields & & fault & \\
\hline Qinjiatun oil and gas fields & \multirow{3}{*}{ Southeast slope belt } & fault & \\
\hline $\begin{array}{l}\text { Xiaochengzi gas-bearing } \\
\text { structure }\end{array}$ & & block fault & \\
\hline Xinli gas-bearing structure & & block fault & \\
\hline Pijai gas fields & Northern Slope & monocline & lithology \\
\hline Pijaigas-bearing structure & $\begin{array}{l}\text { Pijia Second } \\
\text { concavee }\end{array}$ & fault & lithology \\
\hline $\begin{array}{c}\text { Shuanglong Oil-bearing } \\
\text { structures }\end{array}$ & $\begin{array}{l}\text { Shuanglong Second } \\
\text { concave }\end{array}$ & block fault & lithology \\
\hline
\end{tabular}




\section{Regional reservoir characteristics}

Pear faulted hydrocarbon distribution has a longitudinal multi-layers, spanning segment length wells, oil and gas which are concentrated in the vicinity of the plane source rocks with a characteristic ring with distribution. Predecessors from different angles, analyze the pear rift hydrocarbon accumulation law, obtained a series of conclusive understanding of the pear rift guiding role in oil and gas exploration. If the researchers believe that nearly traps have a very excellent source reservoir conditions, and analyzed early fracture and migration of source rocks and reservoir distribution relationship, late rupture and hydrocarbon accumulation, late and secondary structure relations reservoir distribution. (Yang Liying et al .2005) The pear faulted into "Three swell, two concave" structural characteristics, namely three swell: Central tectonic zone, Qin jiatun tectonic belt and leather belt home construction; and during the two concave band (pear furrow district, Xiaokuan furrow area) divided, pear rift deep oil and gas mainly gathered in these three tectonic belt. Three closely related causes tectonic belt and basement faults, Yingcheng, Denglouku late and late tectonic movement of the early generation and accumulation of oil and gas have played a vital role in both local structures formed during is an important place for hydrocarbon accumulation(Yuming et al. 2006). Through the Songliao Basin rift typical profile pear fine interpretation and research, analyzes the four inversion structure with a distinctive structural features and style reversal. Gujiazi-Houwujaizi inversion structure with a "bully-type fault, " featuring fifth sijiazi and sijiazi inversion structure belt, shallow box-shaped anticline showed deep development of "bullying style reverse fault, "Qinjiatun band inversion structures developed in the early half graben over" sharp prismatic "anticline, leather home - Maobei - Zhang jiatun inversion structure with the performance of a small anticline or syncline. These inversion structure of hydrocarbon development in the deep depressions near, generation, migration, accumulation, storage configuration excellent relationship, it is important hydrocarbon traps.

\section{Hydrocarbon accumulation characteristics:}

Pear deep rift rift structure layer reservoir characteristics include two categories, one is mainly lateral migration and reservoir-type reservoir types, one is far from the main source of vertical migration swells the reservoir-type reservoir type.

\section{Near the main source of lateral migration and reservoir-type reservoir type}

Pear deep rift rift structure layer reservoir characteristics include two categories, one is mainly lateral migration and reservoir-type reservoir types, one is far from the main source of vertical migration swells the reservoir-type reservoir type.

This type is the accumulation of deep Huoshiling, Shahezi, Yingcheng hydrocarbon source rocks discharged directly into the reservoir and its immediately adjacent, Lateral migration of oil and gas mainly higher transport efficiency. Reservoir for the role of the mid-rift basin edge alluvial fan deltas directly into deep water, underwater fan body. Mostly due to sand deposited near the source, larger lateral facies, developmental lack of continuity and stability sand, oil and gas limited lateral migration distance. Therefore, this accumulation is present in many types of steep rift zone. Close to the rich hydrocarbon source, migration distance is short, little affected by the late tectonic destruction is its accumulation of favorable conditions, can easily form lithologic traps. But the depth of sand, low maturity, heterogeneity, diagenesis strong, small porosity, low permeability, is its exploration of difficulty.

\section{Far vertical migration source storage type based swells Accumulation types}

In this type of reservoir, deep hydrocarbon source rock in the role of a variety of power along the conducting layer updip lateral migration, after encountering open faults, vertical migration along faults supremacy Ministry Denglouku, Quantou traps gathered into hiding. Trap types, mostly late tectonic block anticline formed, large area, high amplitude, spatial location in the oil and gas 
migration and accumulation of favorable area, and the faults and multiple regional unconformity development, hydrocarbon migration good channel aggregation.

On the plane, they tend to line up with the anticline appears, often across multiple hydrocarbon generation and expulsion center is conducive to hydrocarbon accumulation. Reservoir rocks shallow lake shore, shallow deltaic deposition of gravel, and coarse sandstones, in a fine sandstone porosity larger, higher permeability, and shallow, diagenesis is not very strong. But long-distance transport of oil and gas, loss of capacity, collection efficiency is not high. And the reversal of the tectonic fold preservation has damaging effects on the oil and gas, which are unfavorable factors into reservoirs. For example, Qin Jiatun.

Qin jiatun pear oil and gas fields located in the southeast slope rift zone, for a northeast-trending faults by holding two large block structure, the main reservoir types of structural - lithological reservoirs. Well integrated seismic and Qin jiatun hydrocarbon accumulation mode view, its reservoirs are mainly distributed in the Springs section and Denglouku, mainly due to faults control the formation of Qin jiatun oil and gas fields under the following factors control:

(1)The background has a nose structure, fault complicated broken nose reservoirs in the region to promote the formation of more than one fault block reservoirs. Qin jiatun construction zone on the southeast slope of ancient background basement ramp up development of a wide nose structure with ease, Qin East oil and gas are the main fracture and fracture the formation of traps associated control, adjacent to the main hydrocarbon generation sag, near the source, and the long-term oil and gas migration and accumulation point area, it is advantageous to double oil and gas accumulation, excellent conditions for hydrocarbon accumulation.

(2)The hydrocarbon source rocks is developed. By contrast oil sources confirmed that Qin jiatun tectonic furrow southwest rift stratigraphy Yingcheng, Shahezi the dark mudstone is effective source rocks, type II B III type of kerogen. Yingcheng secretly ratio of $45 \%$, the organic carbon content of $1.0 \%-2.51 \%$, with an average $1.55 \%$; Shahezi secretly ratio of $38 \%$ and $55.7 \%$, Shahezi organic carbon content from $0.72-1.41 \%$, bitumen " $\mathrm{A}$ " is greater than $0.20 \%, 0.01 \%$ higher than the total hydrocarbons, YINGCHENG and Shahezi dark mudstones are good source rocks. Furthermore, from the evolution of the degree of discrimination is at the peak of liquid hydrocarbons and hydrocarbon generation and expulsion history and structure formation and development to match better.

(3)It has good reservoir and cap. Yingcheng area, Shahezi lacustrine-phase, braided river delta and fan delta front semi-deep lake, reservoir development, good reservoir conditions. Yingcheng top and bottom for the development of shale cap rock sound, strong blocking effect on the oil and gas reservoir cap combination is very favorable. Combined stratigraphic overlap pinch, stratigraphic and lithologic traps are widely developed, with the formation of structural - lithological, stratigraphic - lithologic traps superior geological conditions.

(4)The conduit system is developed. Qin jiatun fault, Qin East faults and different genetic faults associated with different geological history of sand, unconformity, for hydrocarbon migration provides a good channel.

(5)Good hydrocarbon preservation conditions. After the end of the district tender reformation minor tectonic movement, the destructive effects of the weak structure of the reservoir, is conducive to hydrocarbon accumulation and preservation, mainly in the oil and gas under Quantou deep strata Yingcheng, Shahezi reservoir is the focus of exploration.

In conclusion: Pear rift has rich oil and gas resources, a large rift within the main hydrocarbon source rock deposition thickness, high abundance of organic matter, organic matter type to III, II 2-based, organic maturity huge resource potential. Overall exhibit features the following three aspects:

(1) Qin jiatun anticline is controled by Qin Dong fracture and its configuration back-breaking shape traps;

(2) Oil and gas oil source faults along vertical migration may, after entering the reservoir by updip trap block aggregation; 
(3) Oil and gas along the lateral migration control Xiaokuan breaking seven trees Shahezi hydrocarbon accumulation, sandstone pinch faulted anticline and is a major trap types.

Therefore, under the premise of the advantages of the construction outlook, if sand is more developed and better match with hydrocarbon migration path off the ring and fracture strengths strengths sand configuration area is mainly based on the principle of favorable area of choice.

Hydrocarbon accumulation is, reservoir, cap, ring static elements and migration, accumulation, bulk dynamic process together, the results of multivariate coupling joint control, according to a preferred principle favorable areas, respectively, from the oil source hydrocarbon migration and benefits of off circle matching and breaking - sand different strengths univariate departure angle configuration optimized accumulation of the advantages of regional,

\section{References}

[1] Fisher Q J, Knipe R J. The Permeability of Faults Within Siliciclastic Petroleum Reservoirs of the North Sea and Norwegian Continential Shelf. Marine and Petroleum Geology, 2001, 18: 1063-1081.

[2] Antonellini, M. \& Aydin, A. Effect of faulting on fluid flow in porous sandstones: petrophysical properties[J]. AAPG. Bulletin, 1994, 78: 335-377.

[3] Aydin, A., Johnson A., Development of faults as zones of deformation bands and as slip surfaces in sandstone[J]. Pure and Applied Geophiscs. 1978, 116:931 942

[4] Thompson A. H. Katz A. J. \& Krohn C. E. The microgeometyr and transport properties of sedimentary rocks[J]. Advances in Physics, , 1987, 36: 625-694.

[5] Knipe, R. J. Faulting processes and fault seal[A]. In: R. M. Larsen, H. Brekke, B. T. Larsen and E. Talleraas, Structural and Tectonic Modelling and its Application to Petroleum Geology[C]. NPF Special Publication 1, Stavanger, 1992: 325-342.

[6] Knipe, R. J. The influence of fault zone processes and diagenesis on fluid flow[A]. In: A. D. Horbury and A. G. Robinson, Diagenesis and Basin Development[C]. AAPG. Studies in Geology, 36. American Association of Petroleum Geologists, Tulsa, OK, 1993: 135-154.

[7] Knipe, R. J. Faulting processes, seal evolution and reservoir discontinuities: an integrated analysis of the ULA Field, Central Graben, North Sea[A]. Abstracts of the Petroleum Group Meeting on Collaborative Research Programme in Petroleum Geoscience between UK Higher Education Institutes and the Petroleum Industry. Geological Soceity, London. 1992b.

[8] Zhang Min. Pear - Oil and Gas Geochemistry of Fulongquan region. The sinopec exploration and development institute, 2011.

[9] Han Shuxia. Pear rift zone focused oil and gas exploration potential analysis and objective evaluation. The sinopec exploration and development institute, 2011

[10] Fan Tailiangiang. Pear faulted sedimentary system and subtle reservoir exploration direction. The sinopec exploration and development institute, 2011. 